\title{
Cytotoxic Activity of the Root and Fruit Extracts of Heptaptera Anisoptera (DC.) Tutin
}

\author{
Fatma Tosun $^{1 *}$, Mahmut Miski² \\ 1 Istanbul Medipol University, School of Pharmacy, Department of Pharmacognosy, Istanbul, Turkey \\ 2 Istanbul University, Faculty of Pharmacy, Department of Pharmacognosy, Istanbul, Turkey
}

\begin{abstract}
Cytotoxic activities of the root and fruit extracts of Heptaptera anisoptera (DC.) Tutin were investigated on the colon cancer COLO2O5 and KM12 cell lines. The dichloromethane extract of the roots of $H$. anisoptera showed cytotoxic activity with $\mathrm{IC}_{50}$ values of 3.1 and $3.9 \mathrm{ug} / \mathrm{mL}$ on the $\mathrm{COLO} 205$ and KM12 cell lines, respectively. Cytotoxic activity of the dichloromethane extract of the fruits were similar to those of root extract with $\mathrm{IC}_{50}$ values of 5.5 and $4.8 \mathrm{ug} / \mathrm{mL}$ on the COLO2O5 and KM12 cell lines, respectively.
\end{abstract}

Keywords: Cytotoxic activity, Heptaptera anisoptera, Apiaceae

\section{INTRODUCTION}

The genus Heptaptera Marg. \& Reuter (Apiaceae) is represented by 10 species worldwide, four of them; H. cilicica (Boiss. \& Bal.) Tutin, H. anisoptera (DC.) Tutin, $H$. anatolica (Boiss.) Tutin and $H$. triquetra (Vent.) Tutin are growing in Turkey ${ }^{1,2}$. Heptaptera species are known to contain sesquiterpene coumarin derivatives ${ }^{3,4}$, these compounds have various biological activities such as; cytotoxicity, P-glycoprotein inhibitory, cancer chemoprevention, anti-inflammatory, antibacterial, antileishmanial, antiviral, antidiabetic, etc..$^{5-9}$.

\section{METHODOLOGY}

\section{Plant Material}

The roots and fruits of Heptaptera anisoptera were collected in the vicinity of Kahramanmaraş in June 2013 and identified by Prof. A. Duran. A voucher specimen (A. Duran 9621) was deposited in the Herbarium of Selçuk University, Faculty of Sciences, Department of Biology (Konya).

*Corresponding Author: Fatma Tosun, e-mail: ftosun@medipol.edu.tr

Fatma Tosun ORCID Number: 0000-0003-2533-5141

Mahmut Miski ORCID Number: 0000-0003-2653-0563

(Received 01 August 2019, accepted 20 September 2019) 


\section{Extraction}

Coarsely powdered roots ( $150 \mathrm{~g}$ ) and fruits (50 g) of the plant were separately and sequentially extracted at room temperature with dichloromethane $\left(\mathrm{CH}_{2} \mathrm{Cl}_{2}\right)$ and methanol. The extracts were individually concentrated in a rotary evaporator under reduced pressure to dryness. Dichloromethane and methanol extracts of the roots were $3.89 \mathrm{~g}, 2.59 \%$ and $9.59 \mathrm{~g}, 6.39 \%$, respectively. Dichloromethane and methanol extracts of the fruits were $5.73 \mathrm{~g}, 11.46 \%$ and $1.97 \mathrm{~g}, 3.94 \%$, respectively. Methanol extract was redissolved in a mixture of methanol/water (10:90) and then partitioned with ethyl acetate (EtOAc), the resulting extracts were separately concentrated in vacuo to dryness. Ethyl acetate and aqueous-methanol extracts of the roots were $1.18 \mathrm{~g}, 0.79 \%$ and 8.41 g, 5.6\%, respectively. Ethyl acetate and aqueous-methanol extracts of the fruits were $0.25 \mathrm{~g}, 0.5 \%$ and $1.72 \mathrm{~g}, 3.44 \%$, respectively.

\section{Cytotoxicity Assay on Colon Cancer Cells}

The assay used for this study was a two-day, two cell line XTT bioassay ${ }^{10}$, an in vitro antitumor colorimetric assay developed by the MTL Assay Development and Screening Section. Colon cancer cell lines used were COLO2O5 and KM12. Cells were maintained and passed weekly in RPMI-1640 medium with phenol red (Gibco, Carlsbad, CA, USA) and supplemented with $2 \mathrm{mM}$ L-glutamine (Quality Biologicals, Inc., Gaithersburg, MD, USA) and 10\% fetal bovine serum (Hyclone, Logan, UT, USA). Cells were placed in a humidified incubator with an atmosphere of $5 \% \mathrm{CO} 2$ and $95 \%$ air and a temperature of $37^{\circ} \mathrm{C}$. Cells were placed in a humidified incubator with an atmosphere of $5 \% \mathrm{CO} 2$ and $95 \%$ air and a temperature of $37^{\circ} \mathrm{C}$. Cells used in the assay were harvested with RPMI-1640 medium, without phenol red (Gibco, Carlsbad, CA, USA) and supplemented with $2 \mathrm{mM}$ L-glutamine (Quality Biologicals, Inc., Gaithersburg, MD, USA) and $10 \%$ fetal bovine serum without antibiotics. Harvested cells were counted using a Cellometer Auto T4 cell counter (Nexcelom Bioscience LLC, Lawrence, MA, USA) and plated in 384-well flat-bottom polystyrene microtiter plates (Nunc, Nunc A/S, Denmark), at a density of 5000 cells/well for $\mathrm{COLO}_{20} 5$ and 5000 cells/well for KM12. The cells were incubated in a $5 \%$ $\mathrm{CO} 2 / 95 \%$ air and $37^{\circ} \mathrm{C}$ incubator for $24 \mathrm{~h}$. After incubation, test samples were added to plates using a Biomek FX robotic liquid handling workstation (Beckman/Coulter, Fullerton, CA, USA). The robot performed eight 2 -fold serial dilutions of the sample and then transferred the sample from the source plate to the assay plate. The plates used were Costar 384-well round-bottom plates (Corning Inc., Corning, NY, USA). Cells were further incubated with samples for $48 \mathrm{~h}$, at which time the XTT reagent was added. Viable cells reduced the 
XTT to a colored formazan product, and after an additional $4 \mathrm{~h}$ incubation period the amount of formazan produced was quantified by absorption at 450 $\mathrm{nm}$, using a $650 \mathrm{~nm}$ reference. Sanguinarine was used on each plate as a positive control.

\section{RESULTS AND DISCUSSION}

This is the first report on the cytotoxic activity of the roots and fruits of $H$. anisoptera. The dichloromethane extracts of the roots and fruits exhibited strong inhibitory activity on the colon cancer COLO2O5 and KM12 cell lines. The ethyl acetate extract of the fruits exhibited strong inhibitory activity on the COLO2O5 cell lines with IC5O value of $4.5 \mathrm{ug} / \mathrm{mL}$ but only a moderate inhibitor activity on KM12 cell lines. The cytotoxic activities observed with these extracts are shown in Table 1.

Table 1. Cytotoxic activities of extracts

Cytotoxic activity $\left({ }^{\left(C_{50}\right.}\right.$ values in $\left.\mathrm{ug} / \mathrm{mL}\right)$

\begin{tabular}{ccl} 
Extracts & COLO205 & KM12 \\
\cline { 2 - 3 } 1 & 3.1 & 3.9 \\
2 & $>50$ & 20.5 \\
3 & $>50$ & $>50$ \\
4 & 5.5 & 4.8 \\
5 & 4.5 & 15.2 \\
6 & $>50$ & $>50$
\end{tabular}

1: $\mathrm{CH}_{2} \mathrm{Cl}_{2}$ extract of the roots; 2: EtOAc extract of the roots; 3: aqueous-methanol extract of the roots

4: $\mathrm{CH}_{2} \mathrm{Cl}_{2}$ extract of the fruits; 5: EtOAc extract of the fruits; 6 : aqueous-methanol extract of the fruits

The dichloromethane extract of the roots of $H$. anisoptera showed cytotoxic activity with $\mathrm{IC}_{50}$ values of 3.1 and $3.9 \mathrm{ug} / \mathrm{mL}$ on the COLO2O5 and KM12 cell lines, respectively. The cytotoxic activities of dichloromethane extract of the fruits were similar to those of root extract with $\mathrm{IC}_{50}$ values of 5.5 and $4.8 \mathrm{ug} / \mathrm{mL}$ on the COLO2O5 and KM12 cell lines, respectively. The ethyl acetate extract of the fruits showed cytotoxic activity with $\mathrm{IC}_{50}$ values of 4.5 and $15.2 \mathrm{ug} / \mathrm{mL}$ on the COLO2O5 and KM12 cell lines, respectively. Whereas, the ethyl acetate extract of the roots showed a moderate cytotoxic activ- 
ity with $\mathrm{IC}_{50}$ values of $20.5 \mathrm{ug} / \mathrm{mL}$ on the KM12 cell lines but no inhibitor activity up to $5 \mathrm{O} \mathrm{ug} / \mathrm{mL}$ on the COLO205 cell lines. Previously, Appendino et al. reported umbelliprenin, badrakemin, badrakemone, colladonin (major compound), colladin, 14-acetoxybadrakemin, 14-acetoxybadrakemone, 14-hydroxycolladonin from the chloroform extract of the roots and more polar compounds samarcandin, samarcandone, conferol, conferone, feselol, 9,10,11-trihydroxyumbelliprenin, 9,10,11-5'-tetrahydroxyumbelliprenin, 9, 10, 5'-triacetoxy-11-hydroxyumbellipreni, 10, 11, 5'-trihydroxyumbelliprenin from the chloroform extract of the fruits of $H$. anisoptera collected from Diyarbakır in June $1991^{3,11,12}$. Cytotoxic activity of certain sesquiterpene coumarins were described earlier ${ }^{4,5}$, thus, the cytotoxic compound(s) of the roots and fruits of $H$. anisoptera may be this type of compound(s). Bioactivity guided fractionation of the dichloromethane extracts of the roots and fruits of $H$. anisoptera is planned to isolate and identify their cytotoxic principles.

\section{ACKNOWLEDGMENT}

We thank Dr. John Beutler, Molecular Targets Laboratory, CCR, NCI, Frederick, MD, U.S.A. for the cytotoxic activity testing.

We thank Prof. A. Duran for the collection and identification of plant material. 


\section{REFERENCES}

1. The Plant List, A Working List of All Plant Species, Accessed July 30, 2019 at http://www. theplantlist.org/tpl1.1/search?q=Heptaptera

2. Herrnstadt, I.; Heyn, C.C.; Heptaptera Marg. \& Reuter. In Flora of Turkey and the East Aegean Islands, Davis, P., Ed.; Edinburgh University Press, Edinburgh, 1972; Vol. 4, pp 388-39o.

3. Appendino, G.; Özen, H. Ç.; Tagliapietra, S.; Cisero, M. Coumarins from Heptaptera anisoptera. Phytochemistry 1992, 31, 3211-3213.

4. Tosun, F.; Beutler, J. A.; Ransom, T. T.; Miski, M. Anatolicin, a Highly Potent and Selective Cytotoxic Sesquiterpene Coumarin from the Root Extract of Heptaptera anatolica. Molecules 2019, 24, 1153-1160.

5. Nazari, Z. E.; Iranshahi, M. Biologically active sesquiterpene coumarins from Ferula species. Phytother. Res. 2011, 25, 315-323.

6. Gliszczynska, A.; Brodelius, P. E. Sesquiterpene coumarins. Phytochem. Rev. 2012, 11, 77-96

7. Dastan, D.; Salehi, P.; Aliahmadi, A.; Gohari, A. R.; Maroofi, H.; Ardalan, A. New coumarin derivatives from Ferula pseudalliacea with antibacterial activity. Nat. Prod. Res. 2016, 30, 2747-2753.

8. Amin, A.; Tuenter, E.; Cos, P.; Maes, L.; Exarchou, V.; Apers, S.; Pieters, L. Antiprotozoal and antiglycation activities of sesquiterpene coumarins from Ferula narthex exudate. Molecules, 2016, 21, 1287-1296.

9. Iranshahi, M.; Rezaee, R.; Najafi, M. N.; Haghbin, A.; Kasaian, J. Cytotoxic activity of the genus Ferula (Apiaceae) and its bioactive constituents. Avicenna J. Phytomed. 2018, 8, 296-312.

10. Devkota, K. P.; Covell, D.; Ransom, T.; McMahon, J. B.; Beutler, J. A. Growth inhibition of human colon carcinoma cells by sesquiterpenoids and tetralones of Zygogynum calothyrsum, J. Nat. Prod. 2013, 76, 710-714.

11. Appendino, G.; Özen, H. Ç.; Nano, G. A.; Cisero, M. Sesquiterpene coumarin ethers from the genus Heptaptera. Phytochemistry 1992, 31, 4223-4226.

12. Appendino, G.; Özen, H. Ç.; Jakupovic, J. A sesquiterpene coumarin ether and a coniferyl ester from Heptaptera anisoptera. Fitoterapia 1993, 64, 505-506. 